\title{
Antibacterial Potential of Selected Antiurolithiatic Plants on Bacterial Pathogens Isolated from Urinary Tract Infection
}

\author{
M. Suma ${ }^{1}$ B. Vasanthakumari ${ }^{2}$ and N. Vijayakumar ${ }^{1}$ \\ ${ }^{1}$ P.G. and Research Department of Botany, S.T.Hindu College, Nagercoil, India \\ ${ }^{2}$ Sree Ayyappa College for Women, Chunkankadai, Nagercoil, India \\ *Corresponding author
}

Keywords

Aervalanata, Antiurolithiatic, Bacteriuria, Disc diffusion, Scoparia dulcis.

\section{Article Info}

Accepted:

13 August 2016 Available Online: 10 September 2016

\section{A B S T R A C T}

The incidence of Urinary Tract Infection (UTI) was analysed among the patients of Kanyakumari Government Medical College and Hospital, Asaripallam, Kanyakumari district to identify the common bacteria causing UTI and to check antibacterial potential of selected plant extracts against the pathogens. The results showed that $28 \%$ of samples yielded significant bacteriuria. Among the infected persons, females were more and percentage of infection was higher in the age group above 55 followed by $35-55$ in both sexes. E.coli has been found to be the most common UTI bacteria followed by Klebsiella. Four bacterial strains i.e. E.coli, Klebsiella, Pseudomonas and Proteus were isolated from UTI samples and antibacterial activity of aqueous and methanol extracts of Aerva lanata and Scoparia dulcis were carried out by disc diffusion method. The highest zone of inhibition was observed in the extracts of Aerva root for E.coli and Klebsiella where as in Pseudomonas it was in the fruit extracts of Scoparia. Proteus was resistant against all extracts with no or little zone of inhibition.

\section{Introduction}

Urinary Tract Infection (UTI) is described as microbial invasion of kidneys, ureters, bladder or urethra and is the second most common clinical symptom for experimental antimicrobial treatment in primary and secondary lane. It is defined as the proliferation of active microorganisms inside the urinary channel which are harmful to their environment (Singh et al., 2012). The infecting bacteria normally constitute the faecal flora, the infection is initiated when the urine flow is obstructed by some or other reasons such as calculi, tumours, etc. (Saint et al., 2002). The infecting bacteria invade urethra and move to bladder mucosa, multiply and colonize to cause inflammation. Presence of $1 \times 10^{5}$ or more colonies per millimetre in urine specimens indicates bacteriuria (Stauffer $e t$ al., 2004). UTI is prevalent in all age groups from neonates to old age and is mostly caused by gram negative bacteria belonging to Enterobacteriaceae. If the infection is not controlled, the infecting microbes got resistance to the applied antibiotics intrinsically and a drug resistant cell 
survives and predominates with concomitant bacterial genetic exchange mechanisms (McMurry and Levy, 2011). Analysing antibiotic susceptibility pattern of uropathogens helps to overcome the difficulties caused due to antibiotic resistance and guides in choosing appropriate antibiotics (Chowdhury and Parial, 2015). Alternative systems which have great potential for producing new drugs of great benefit to mankind are employed for controlling UTI. This has led to the search of new antibacterial agents with broad spectrum activities from natural sources particularly from medicinal plants. Medicinal plants are valuable sources of novel antibacterials for preventing and controlling microbes. So there is an urgent need to develop antibacterial drugs for UTI.

\section{Materials and Methods}

Survey for UTI samples among the urine samples received for culture and sensitivity tests in microbiology lab of Kanyakumari Government Medical College and Hospital, Asaripallam was conducted during August 2014 - July 2015. All the data's regarding the patents, urine culture and patogens were collected and tabulated.

\section{Isolation of UTI bacteria}

Microorganisms causing UTI were isolated from the urine samples of infected patients. The urine samples were collected from Microbiology Department of Kanyakumari Medical College and Hospital, Asaripallam. To isolate UTI bacterial strains, samples were serially diluted and a loop full of diluted samples were streaked on MacConkey agar and Nutrient agar plates (Hi Media, India \& Merck, Germany) and incubated at $37 \pm 2^{\mathrm{c}} \mathrm{c}$ for $24 \mathrm{hrs}$. After incubation colonies were selected and identified based upon gross colony morphology, standard biochemical tests and also with the help of Bergeys Manual of Systematic Bacteriology (Mac Faddin, 2000, Kreig and Holt, 1984). The identified specimens were streaked on agar slant and stored in refrigerator for further studies.

Plant material: Aerva lanata L. Juss., Scoparia dulcis L.

\section{Preparation of extract}

Plant materials such as Scoparia dulcis and Aerva lanata were collected from Chunkankadai, Kanyakumari district and washed in running water. Plant parts were separated and again cleaned with distilled water and then dried under shade. Dried materials were then powdered with the help of a mixer grinder. $50 \mathrm{~g}$ of each powder was packed inside the filter paper and extracted using Methanol and water in a soxhlet apparatus. They were filtered using whatman filter paper No. 42 and concentrated in a rotary evaporator. The concentrated extracts were dried in a water bath and stored in refrigerator for further analysis.

\section{Disc diffusion method}

The sensitivity tests were conducted by standard disc diffusion method (Bauer et al., 1966). Sub cultures of the tested organisms were made on the previous day. A loop full of isolated colonies was inoculated in to $5 \mathrm{ml}$ of nutrient broth in a test tube, incubated for 12 hours at $37^{\circ} \mathrm{C}$. This actively growing bacterial cultures were used for antibacterial screening. Pour $15-20 \mathrm{ml}$ of Muller Hinton agar medium into sterilized petri plates placed in a laminar air flow hood and allowed to solidify. After 30 minuites the plates were covered, labelled and inverted. Using a sterilized cotton swab the inoculum was evenly spread over the surface of 
Muller Hinton agar plate and kept at room temperature for 3-5 minutes for drying. The sterile filter paper discs $(6 \mathrm{~mm})$ were impregnated with plant extracts $(100 \mu \mathrm{ml})$ and left to dry at room temperature. Controls used were ampicillin $10 \mathrm{mcg}$ and nitrofuran $300 \mathrm{mcg}$ discs. These discs were placed carefully over the surface of the medium using a sterile forceps and gently press to ensure complete contact with the agar surface. Incubate the plates at $37^{\circ} \mathrm{C}$ for 24 hours. Following incubation, measure the zone of inhibition to nearest millimetre using a ruler. All the experiments were done in triplicates and the mean zone of inhibition was taken.

\section{Results and Discussion}

In the present survey for UTI infections, among the 2177 urine samples obtained during the study period (August 2014- July 2015) for culture and sensitivity tests 621 (28.5\%) yield significant bacteriuria. Sex wise analysis showed $60 \%$ of the infected samples were from females and $40 \%$ from males which showed that the incidence of UTI is higher among females than males. These results are in agreement with the results of similar studies (Chowdhury and Parial, 2015). This may be due to anatomical pre deposition or urothelial mucosal adherence to the mucopolysaccharide lining or other host factors (Schaffer et al., 2001). Females take less amount of water may be another reason. In females UTI commonly occurs in an anatomically normal urinary tract, but in males and children, UTI generally reveals a urinary tract lesion that must be identified by imaging and must be treated to suppress the cause of infection and prevent recurrence (Singh et al., 2012). Month wise analysis showed that highest percentage was seen in May (41\%) followed by April (37\%) and November $(31 \%)$. The hot climate during these months may cause increased infection. UTI infection was prevalent in all age groups from neonatal to old age. Old age groups $(<55)$ were found to be more susceptible in both males and females $(51 \%$, $39 \%$ ). This is followed by adults in age group 35-55. Least infection was observed in adolescents of age group 13-18. In case of females infections in young adults were more $(21 \%)$ comparing to males (9\%) (Table.1). But in a study by Chowdhury and Parial (2015) highest number of patients with UTI were found in the age group ranging $20-40$ followed by $1-5$ and then the age range $40-65$.

Among the uropathogens, 29\% of infected sample has E.coli, $27 \%$ contains a mixed population, $20 \% \quad$ Klebsiella, $\quad 10 \%$ Pseudomonas followed by small percentages of Proteus, Citrobacter, Enterococci etc. So the most common uropathogens in our study were E.coli and Klebsiella. The previous studies by Ronald (2002), Chowdhury and Parial (2015), Olafsson et al., (2000) and Tabassum et al., (2013) support this finding. Isolation of UTI pathogens from tribals of West Bengal revealed E.coli as the most common bacterium and amikacin as the effective antibiotic (Maji et al., 2016). In a survey on UTI associated with the three most common uropathogenic bacteria showed that the first two agents ie, E.coli and Klebsiella in different seasons were similar while the third one was variable (Behzadi et al., 2008). According to Linhares et al., (2003) there was difference in bacteria implicated in UTI varied with sex i.e., Pseudomonas is common in man than women. Such a difference cannot be seen in the present study.

Multiple antibiotic resistances were reported in UTI and were significantly increased in recent years. Several potent antibiotics are 
available for treatment but increasing drug resistance of pathogens has been a great problem for many years. The first bacterium that was detected to be resistant to several antibiotics was reported in Japan during 1950s (Schlegel \& Schmidt, 1985). UTI is a complicated problem which has to phase new challenges due to change in etiology and antibacterial resistance of pathogens over years. Extensive use and abuse of antibiotics also contribute to changesin the microbial profile of urinary tract isolates (Mady and Helmi, 2003). So there is an urgent need for new formulation that resists the growth of UTI bacteria. To test the efficiency of selected antiurolithiatic plants, Aerva lanata and Scoparia dulcis against UTI inducing flora, bacteria were isolated from urine of UTI infected patients. A total of forty urine samples collected from hospital only twenty-five yield bacteriuria. Four types of bacteria were isolated and identified, E.coli (60\%), Klebsiella (16\%), Psuedomonas (8\%) and Proteus (4\%) and rest were contaminated. Similar UTI pathogens have been reported by Fuad et al., (2012), Al-Jiffri et al., (2011). Nitrofuran $300 \mathrm{mcg}$ and Ampicillin10mcg were used as standard.

Table.1 Analysis of UTI among the urine samples

\begin{tabular}{|c|c|c|c|c|c|c|c|c|c|c|c|c|c|c|c|}
\hline \multirow{2}{*}{ Month } & \multirow{2}{*}{$\begin{array}{l}\text { Total no. } \\
\text { samples }\end{array}$} & \multirow{2}{*}{$\begin{array}{l}\text { No. of } \\
\text { infected } \\
\text { samples }\end{array}$} & \multirow{2}{*}{$\begin{array}{c}\% \text { of } \\
\text { infection }\end{array}$} & \multicolumn{6}{|c|}{ Age groups Males } & \multicolumn{6}{|c|}{ Age groups Females } \\
\hline & & & & $>12$ & $\begin{array}{l}13- \\
18 \\
\end{array}$ & $\begin{array}{l}19- \\
34 \\
\end{array}$ & $\begin{array}{l}35- \\
55\end{array}$ & $<55$ & $\begin{array}{c}\text { Tot } \\
\text { al }\end{array}$ & $>12$ & $\begin{array}{l}13- \\
18\end{array}$ & $\begin{array}{l}19- \\
34 \\
\end{array}$ & $\begin{array}{l}35- \\
55 \\
\end{array}$ & $<55$ & Total \\
\hline August & 163 & 35 & 21.47 & 2 & - & 1 & 6 & 5 & 14 & - & - & 6 & 7 & 8 & 21 \\
\hline September & 153 & 49 & 32.03 & 5 & 1 & 4 & 2 & 10 & 22 & - & - & 7 & 5 & 15 & 27 \\
\hline October & 172 & 43 & 25.00 & 3 & - & 1 & 7 & 10 & 21 & 4 & - & 6 & 3 & 9 & 22 \\
\hline November & 200 & 63 & 31.50 & 2 & - & 2 & 4 & 10 & 18 & 10 & - & 11 & 15 & 9 & 45 \\
\hline December & 159 & 38 & 23.90 & 1 & - & 5 & 5 & 8 & 19 & 1 & 1 & 1 & 7 & 9 & 19 \\
\hline January & 198 & 58 & 29.29 & 3 & - & 3 & 1 & 12 & 19 & 3 & - & 9 & 12 & 15 & 39 \\
\hline February & 148 & 31 & 20.95 & 2 & 1 & - & 3 & 7 & 13 & 3 & - & 5 & 4 & 6 & 18 \\
\hline march & 163 & 42 & 25.77 & 3 & - & - & 6 & 7 & 16 & 2 & - & 8 & 6 & 10 & 26 \\
\hline April & 142 & 53 & 37.32 & 2 & - & 1 & 6 & 9 & 18 & 3 & 1 & 3 & 13 & 15 & 35 \\
\hline May & 163 & 67 & 41.10 & 7 & - & 1 & 4 & 14 & 26 & 6 & 2 & 7 & 12 & 14 & 41 \\
\hline June & 228 & 72 & 31.58 & 7 & 1 & 2 & 8 & 17 & 35 & 4 & 2 & 4 & 9 & 18 & 37 \\
\hline July & 288 & 70 & 24.31 & 5 & - & 2 & 3 & 18 & 28 & 5 & 1 & 10 & 10 & 16 & 42 \\
\hline grant total & 2177 & 621 & 28.53 & 42 & 3 & 22 & 55 & 127 & 249 & 41 & 7 & 77 & 103 & 144 & 372 \\
\hline
\end{tabular}


Table.2 Antimicrobial activities of extracts of Aerva lanata and Scoparia dulcis

\begin{tabular}{|c|c|c|c|c|c|c|c|c|c|c|c|c|c|c|}
\hline \multirow{4}{*}{$\begin{array}{l}\text { Name of } \\
\text { bacteria }\end{array}$} & \multicolumn{14}{|c|}{ Zone of inhibition (mm) } \\
\hline & \multicolumn{4}{|c|}{ Aerva lanata } & \multicolumn{8}{|c|}{ Scoparia dulcis } & \multicolumn{2}{|c|}{ Control } \\
\hline & \multicolumn{2}{|c|}{ Aerial } & \multicolumn{2}{|c|}{ Root } & \multicolumn{2}{|c|}{ Stem } & \multicolumn{2}{|c|}{ Leaf } & \multicolumn{2}{|c|}{ Fruit } & \multicolumn{2}{|c|}{ Root } & \multirow{2}{*}{$\begin{array}{c}\text { nitrofuran } \\
300 \mathrm{mcg}\end{array}$} & \multirow{2}{*}{$\begin{array}{c}\text { Ampicillir } \\
10 \mathrm{mcg}\end{array}$} \\
\hline & Aq. & Met. & Aq. & Met. & Aq. & Met & Aq. & Met. & Aq. & Met. & Aq. & met & & \\
\hline E.coli & - & 16 & - & 21.4 & - & - & - & - & 17.1 & 20.8 & - & - & 14.2 & 15.3 \\
\hline Klebsiella & 5.8 & 6.1 & 12.00 & 11.2 & - & 6.1 & - & 10.6 & - & 8.2 & 7.2 & 5.8 & 12.5 & 7.4 \\
\hline Pseudomonas & - & 8.5 & 8.00 & 8 & - & - & - & 14.1 & 13.2 & 11.2 & - & - & - & 17 \\
\hline Proteus & - & - & - & -- & - & - & - & 6 & & 6.5 & - & - & - & - \\
\hline
\end{tabular}

*All the values are the mean of triplicate experiments

Fig.1 E.coli

Figure:2 Klebsiella

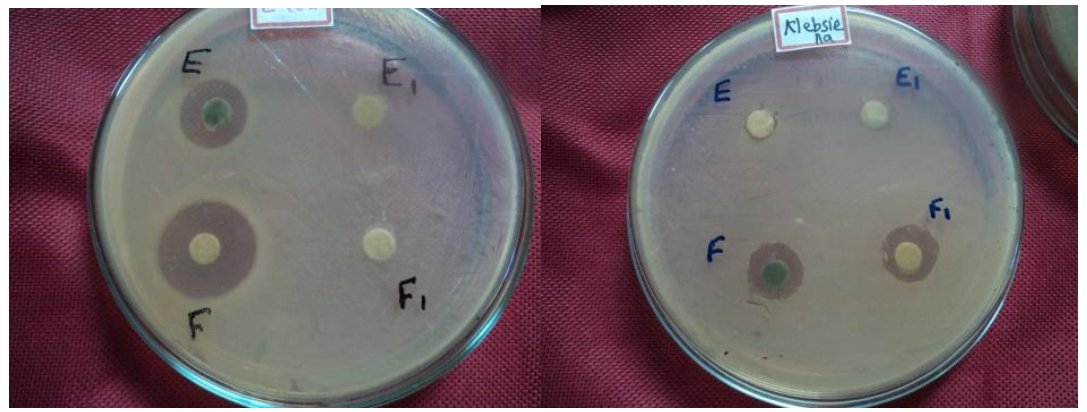

E-Aerva aerial Methanol extract $\mathrm{E}_{1}$-Aerva aerial Aqueous extract F-A root Methanol extract $\quad \mathrm{F}_{1}$-Aerva root Aqueous extract

The results of antibacterial analysis showed that the extracts of Aerva lanata were more susceptible to clinical isolates of UTI pathogens. The zone of inhibition of methanol extract of Aerva lanata root (21.3mm) and Scoparia fruit (20.6) showed higher activity than that of control nitrofuran and ampicillin (14.2 and 15.3) while Aerva aerial parts showed $15.5 \mathrm{~mm}$ inhibition against E.coli. There for the whole plant of Aerva lanata and fruit of Scoparia dulcis has the power to inhibit E.coli. In case of Scoparia the fruit extract was found to be effective against all tested bacteria having the highest zone of inhibition 20.8 against E.coli. Klebsiella has zone of inhibition in all tested plant parts. Pseudomonas showed zone of inhibitions against Aerva parts, Scoparia leaf and fruit. Proteus, a less common UTI bacterium was found to be resistant to all the extract with little or no zone of inhibition (Table 2, Figures1-2)
Muller Hinton agar appears to be the best medium for antibacterial susceptibility tests and the same was used in the present study. Methanolic extracts showed more activity than aqueous extracts. This may be due to higher activation or solubility of biologically active compounds such as alkaloids, flavonoids, terpenoids etc. in organic solvents (de Boer et al., 2005). Antibacterial activity of Euphorbia hirta, Erythrophelum suaveolens and Thevetia peruviana against UTI causing bacteria showed highest activity in methanolic extracts (Singh et al., 2012). In another study ethanolic extract of Scoparia dulcis showed activity against E.coli, Styphylococcus aureus and Shigella dysenteriae (Uddin et al., 2014).

Susceptibility tests for UTI bacteria showed highest degree of resistance to gentamycin, nalidixic acid, trimethoprim sulphamethaoxazole, clotrimazole and cefotaxime 
which are commonly prescribed for UTI treatment. The antibiotics which are effective up to some extent were ampicillin, norfloxacin and tetracycline (Tabassum et al., 2013).

According to Valsalakumari et al., (2014) ethanolic extracts of Scoparia dulcis showed zone of inhibition only for gram positive bacteria, while gram negative E.coli was resistant. In another study using the same extract by Mohandas et al., (2014) against human pathogens Streptococcus (gram positive) and Pseudomonas (gram negative) showed zones of inhibition for both bacteria suggested the presence of broad spectrum antibiotic compound. In the present study the fruit methanolic extract had significant zone of inhibition.

The samples tested for antimicrobial activity in this study may have some bioactive compounds that were potent and further investigations were needed to identify the compound in pure form.

\section{References}

Al-Jiffri, O., Zahira, M.F., El-Sayed, and Al-Sharif, F.M. 2011. Urinary Tract Infection with Escherichia coli and Antibacterial Activity of Some Plant Extracts. Inter. J. Microbiol. Res., 2(1): 01-07.

Bauer, A.W., Kirby, W.M.M., Serris, J.C. and Turck, M. 1966. Antibiotic susceptibility testing by a standardized single disc method. American J. Clin. Pathol., 45: 493-496.

Behzadi, P., and Behzadi, E. 2008. The microbial agents of urinary tract infections at central laboratory of Dr. Shariati Hospital Tehran, Iran. Turk kiln Tip Bilim. 28: 445-449.

Chowdhury, S. and Parial, R. 2015.
Antibiotic susceptibility patterns of bacteria among urinary tract infection patients in Chittagong, Bangladesh. SMU Med. J., 2: 1: 114-126.

de Boer, H.J., Kool, A., Broberg, A., Mziray, W.R., Hedberg, I. and Levenfors, J.J. 2005. Antifungal and Antibacterial Activity of Some Herbal Remedies from Tanzania. $J$. Ehnopharmacol., 96: 461-469.

Fuad, M.M.H., Ferdowsy, H,. Hossain, M.N., Foysal, M.J. and Rahman, M.M. 2012. InVitro Antibacterial Activity of Common Antibiotics and Herb Extracts to Clinical Isolates of Escherichia coli Collected from UTI Patients. Inter. J. Res. Pharma. Biomed. Sci., 3(2): 987-992.

Kreig, R.N. and Holt, G.J. 1984. In Bergey's Manual of Systematic Bacteriology. William and Wilkins Co. Baltimore.

Linhares, I., Raposo, T., Rodrigues, A. and Almeida, A. 2013. Frequency and antimicrobial resistance pattern patterns of bacteria implicated in commonly urinary tract infections: a ten- year surveillance study(20002009). BMC infect. dis., 13-19.

Mac Faddin, F.J. 2000. Biochemical tests for identification of Medical Bacteria. $3^{\text {rd }}$ edition., Philadelphia: Lippincott Williamsand Wilkins.

Mady, Helmi. 2003. Urinary tract infection pathogens and antibiotic sensitivity patterns in hospitalized infants and children in Al-jahra Hospital, Kuwait. Egyptian. J. Med. Microbiol., 12: 415420.

Maji, S.K., Mandal, P.K., Panja, C., Dolai, T.K., Samanta, A., Kundu, R.K. and Mondal, K.C. 2016. Prevalance and antibacterial susceptibility pattern of aerobic bacteria causing urinary tract infection in tribal population in rural part of West Bengal, India. Int. J. 
Curr. Microbiol. App. Sci., 5: 6: 406412.

McMurry, L.M. and Levy, S.B. 2011. The periplasmic protein mppA is not involved in regulation of mar $\mathrm{A}$ in Escherichia coli. Antimicrob. Agen. Chemother., 55: 4939-4942.

Mohandas, C.K., Valsalakumari, P.K., Willium, H. and Narayanan, N. 2014. Antibacterial activity of Clerodendronin fortunatum and Scoparia dulcis- A comparative study. IOSR J. Phar. Bio. Sci., 9(6): 25-29.

Olafsson, M., Kristinsson, K.G., Sigurdsson, J.A. 2000. Urinary tract infections, antibiotic resistance and sales of antimicrobial drugs--an observational study of uncomplicated urinary tract infections in Icelandic women. Scand J. Prim. Health Care, 18: 35-8.

Ronald, A. 2002. The etiology of urinary tract infection: traditional and emerging pathogens. Am. J. Med., 113: 14-9.

Saint, S., Lipsky, B. and Goold, S.D. 2002. Indwelling urinary catheters: a one point resistant Ann. Intern. Med. 137: 125-127.

Schaffer, A.J., Raja, N., Cao, Q., Anderson, B.E., Pruden, D.L., Sensibar, J. and Duncan, D.J.L. 2001. Host pathogenesis inurinary tract infection.
Int. J. Antimicrob. Agents, 17: 245251.

Schlegel, H.G. and Schmidt, K. 1985. General microbiology. German: George Thieme.

Singh, V., Jaryal, M., Gupta, J. and Kumar, P. 2012. Int. J. Drug Res. Tech., 2(3): 263-267.

Stauffer, C.M., Weg, B.V.D., Donadini, R., Ramelli, P.G., Marchand, S. and Bianchetti, M.G. 2004. "Family history and behavioral abnormalities in girls with recurrent urinary tract infections A controlled study"J. Urol., 171: 1663-1665.

Tabassum, H., Ali, M.N., Al-Jameil, N., and Kahn, F.A. 2013. Int. J. Curr. Microbiol. Appl. Sci., 2: 353-368.

Uddin, J., Chowdhury, R.M. and Shanju, T.R. 2014. In vitro identification of antibacterial properties of Scoparia dulcis and Mikaniacordata, two common medicinal plants of Bengladesh. Int. J. Ap. Sci. Eng. Res., 3: 5 .

Valsalakumari, P.K., Narayanan, N., Parimala Devi, B., Mohandas, C.K. and Willium, H. 2014. Studies on antimicrobial activity of Scoparia dulcis. World J. Phar and Phar. Sci., 3(10): 600-613.

\section{How to cite this article:}

Suma, M., B. Vasanthakumari and Vijayakumar, N. 2016. Antibacterial Potential of Selected Antiurolithiatic Plants on Bacterial Pathogens Isolated from Urinary Tract Infection. Int.J.Curr.Microbiol.App.Sci. 5(9): 242-248. doi: http://dx.doi.org/10.20546/ijcmas.2016.508.027 